\title{
Cadmium uptake, translocation, and redistribution affect $C d$ accumulation in grain of common wheat (Triticum aestivum L.) cultivars
}

\section{Yiran Cheng}

Sichuan Agricultural Univerdity

\section{Xu Zhang}

Sichuan Agricultural University

\section{Sha Wang}

Sichuan Agricultural University

\section{Xue Xiao}

Sichuan Agricultural University

Jian Zeng

Sichuan Agricultural University

Houyang Kang

Sichuan Agricultural University

\section{Xing Fan}

Sichuan Agricultural University

\section{Lina Sha}

Sichuan Agricultural University

\section{Haiqin Zhang}

Sichuan Agricultural University

\section{Yonghong Zhou}

Sichuan Agricultural University

Yi Wang ( $\sim$ Wangyi@sicau.edu.cn )

Sichuan Agricultural University https://orcid.org/0000-0003-0018-2716

\section{Research article}

Keywords: wheat, cadmium, grain accumulation, translocation, redistribution

Posted Date: April 30th, 2020

DOI: https://doi.org/10.21203/rs.3.rs-22672/v1

License: (a) This work is licensed under a Creative Commons Attribution 4.0 International License. Read Full License 


\section{Abstract \\ Background}

To study the cadmium ( $\mathrm{Cd}$ ) accumulation in wheat grain, we evaluated the grain $\mathrm{Cd}$ concentrations of 46 common wheat cultivars grown at two sites in Sichuan, China and selected five different grain $\mathrm{Cd}$ accumulators (a high-Cd accumulator ZM18, four low-Cd accumulators YM51, YM53, SM969 and CM104) to explore the physiological processes of $\mathrm{Cd}$ accumulation in the grain of wheat grown under varying degrees of Cd stress.

\section{Results}

Our results showed that the $\mathrm{Cd}$ concentration in grain differed among genotypes. Under low-Cd stress, the grain $\mathrm{Cd}$ concentration was correlated with the $\mathrm{Cd}$ translocation factor (TF) of roots to grain and all the $\mathrm{Cd}$ redistribution factors (RFs). Compared with the ZM18, the cultivars YM53 and SM969 accumulated less Cd in the grain due to low $\mathrm{Cd}$ redistribution from lower stems and older leaves to grain. The low-Cd accumulators YM51 and CM104 were due to low Cd transport from roots to grain, and low Cd redistribution from glumes, flag leaves, lower stems, and older leaves to grain. Under high-Cd stress, the ZM18, YM53, and SM969 accumulated significantly more $\mathrm{Cd}$ in the grain, root and other tissues than did YM51 and CM104. Correlation analyses showed that the grain $\mathrm{Cd}$ concentration of wheat under high $\mathrm{Cd}$ stress was positively correlated with the $\mathrm{Cd}$ concentration in each tissue and the TFs of roots to grains, rachis, internode 1 and flag leaves.

\section{Conclusions}

Cd translocation directly from roots to grain and Cd redistribution from shoots to grain determines the Cd accumulation in grain of wheat cultivars under low-Cd stress. Cd uptake by root and then synchronously transported to new shoots determined the differences of $\mathrm{Cd}$ accumulation in the grain of wheat cultivars under high Cd stress.

\section{Background}

Cadmium (Cd) is a toxic heavy metal that is not biodegradable and is harmful to all living organisms. Many arable soils in the world are contaminated by $\mathrm{Cd}$, which is released from industrial and agricultural processes (The Ministry of Environmental Protection, 2014; Liu et al., 2016; Perrier et al., 2016). In China, approximately 278,600 ha of arable soils are contaminated by Cd (Zhou and Wang, 2002; Liao et al., 2008; Liu et al., 2015, 2016; Li et al., 2017; http://news.cjn.cn/gnxw/201707/t3034882.htm). Cereal crops grown in Cd-contaminated soils accumulate high concentrations of $\mathrm{Cd}$ in the grain. The direct or indirect consumption of these $\mathrm{Cd}$ polluted products poses potential risks to human health (Grant et al., 2008). Thus, reduction of Cd accumulation in grain is an important goal of crop genetic improvement programs.

Wheat is a major staple food for more than half of the world's population. However, increasing areas of arable soils of wheat-growing regions, such as the Yangtze River Basin and the Huang-Huai-Hai Plain in China, have 
become contaminated by $\mathrm{Cd}$ (Liao et al., 2008). Many wheat cultivars grown in Cd-contaminated soils accumulate $\mathrm{Cd}$ in grain to more than the recommended limit of $0.2 \mu \mathrm{g} / \mathrm{g}$, as proposed by the Codes Alimentarius Commission (2005). Therefore, wheat is the main contributor to the average daily dietary intake of Cd in many countries and regions, such as Japan, America, Sweden, and Iran (Greger and Löfstedt, 2004; Stolt et al., 2006; Kubo et al., 2008; Jafarnejadi et al., 2011; Liang et al., 2017). There is an urgent need to limit $\mathrm{Cd}$ accumulation in grain. Wheat grain accumulates $\mathrm{Cd}$ by three main physiological processes: $\mathrm{Cd}$ uptake by roots; Cd transport from roots to shoots; and then Cd redistribution from shoots to grain (Clemens et al., 2002; Arduini et al., 2014; Li et al., 2017). The accumulation of $\mathrm{Cd}$ in wheat grain is controlled by genetic factors, and is also affected by environmental conditions (Greger and Löfstedt, 2004; Stolt et al., 2006; Kubo et al., 2008; Jafarnejadi et al., 2011; Liang et al., 2017). To reduce the Cd concentration in wheat grain, therefore, it is necessary to know the differences in $\mathrm{Cd}$ accumulation in grain among local wheat varieties and determine the physiological processes that underlie the differences.

In cereals, Cd absorbed by the roots can be directly transported to grain; this process is dependent on the Cd concentration in soil and the retention of Cd in roots. In a previous study on wheat in the United states, the Cd concentration in common wheat grain was not correlated with the retention of Cd in roots of plants grown in soil with low Cd contents (Greger and Landberg, 2008; Kubo et al., 2011; Liang et al., 2017), but was positively correlated with root morphological parameters of plants grown in soil with a high Cd contents (about $2.5 \mathrm{mg} / \mathrm{kg}$ ) (Liang et al., 2017). In other studies, the grain Cd concentration of common wheat was found to be positively correlated with Cd translocation from roots to shoots (Greger and Löfstedt, 2004). A major dominant gene (Cdu1) limiting $\mathrm{Cd}$ translocation from roots to shoots in tetraploid wheat could explain only $20 \%$ of the phenotypic variation in grain Cd concentration in common wheat (Wiebe et al., 2010; Pozniak et al., 2012; Harris and Taylor, 2013; Liu et al., 2019). The Cd concentration in grain was found to be positively correlated with the Cd concentration in shoot (Liang et al., 2017). Together, these findings imply that Cd redistribution from shoots to grain and $\mathrm{Cd}$ accumulation $\mathrm{Cd}$ in shoots are responsible for grain Cd accumulation (Stolt et al., 2006; Kubo et al., 2011, 2016; Liang et al., 2017). However, it is unknown which shoot part (flag leaf, older-leaf, internode 1, lower-stem, rachis and glume) contributes the most $\mathrm{Cd}$ to grain, or retains $\mathrm{Cd}$ to limit its redistribution to grain, in common wheat.

Kubo et al. (2016) reported that differences in Cd sequestration between roots and shoot parts could explain differences in grain Cd concentrations; however, their results were obtained glasshouse experiments in pots containing low $\mathrm{Cd}(0.40 \mathrm{mg} / \mathrm{kg})$. To date, no experiments under open-air condition of field have been conducted to determine how $\mathrm{Cd}$ uptake and accumulation in roots and shoots affect grain $\mathrm{Cd}$ accumulation under low-Cd stress during the wheat growing season. Moreover, common wheat cultivars from different ecotypes show different characteristics of $\mathrm{Cd}$ accumulation. Thus, it is important to evaluate a range of cultivars to reveal the physiological mechanisms of grain $\mathrm{Cd}$ accumulation, and improve the selection of wheat germplasm with low $\mathrm{Cd}$ accumulation. In Sichuan, one of the most seriously Cd-contaminated provinces of China, the Cd concentration of arable soil ranges from 0.06 to $4.76 \mathrm{mg} / \mathrm{kg}$ (Liu et al., 2016). Under high-Cd stress, it is unknown how $\mathrm{Cd}$ is taken up and retention in roots, translocated from roots to shoots, and redistribution from shoots to grain. To answer these questions, we (1) selected several low-Cd accumulators and a high-Cd accumulator after evaluating the grain Cd concentrations of 46 common wheat cultivars; (2) explored the physiological mechanisms of grain $\mathrm{Cd}$ accumulation during the wheat growing season in pot 
experiments with low-Cd stress $(0.40 \mathrm{mg} / \mathrm{kg})$ and high-Cd stress $(4.00 \mathrm{mg} / \mathrm{kg})$ under the open-air conditions, by determining the $\mathrm{Cd}$ concentrations in roots and shoot parts, calculating the $\mathrm{Cd}$ translocation factor (TFs) from roots to shoot parts, and calculating the Cd redistribution factor (RFs) from shoot parts to grain.

\section{Methods}

\section{Plant Materials}

Forty-six Chinese common wheat cultivars (36 of them collected from the Southwest wheat region, and 10 of them collected from Huang-Huai-Hai Plain wheat region) were provided by Prof. Jun Li, from Crop Research Institute, Sichuan Academy of Agricultural Sciences. In this study, all cultivars used to investigate the differences of their grain $\mathrm{Cd}$ accumulation were planted at two sites, Wenjiang and Shifang, which have high Cd contents in arable soils, in Sichuan, China (Liu et al., 2010; Qian et al., 2014). Five cultivars were selected for analyses, which include three low-Cd accumulators, one high-Cd accumulator, and one variable-Cd accumulator. For these cultivars, we investigated the $\mathrm{Cd}$ concentrations in the roots and shoots at the seedling and the mature stages for plants grown in pots under low-Cd and high-Cd stresses in the wheat growing season under open-air environment. The three low-Cd accumulators were Yunmai 51 (YM51) and Yunmai 53 (YM53) from Yunnan and Shumai 969 (SM969) from Sichuan. The high-Cd accumulator was Zhoumai 18 (ZM18) from Henan. The variable-Cd accumulator was Chuanmai 104 (CM104, from Sichuan), its grain Cd concentrations differed significantly between the Wenjiang and Shifang sites.

\section{Field experiment}

To investigate the differences in grain Cd concentrations, the 46 cultivars were grown at the Wenjiang experimental field at Sichuan Agricultural University, and the Shifang upland fields of Chengdu Institute of Biology, Chinese Academy of Science, Sichuan, China, in the 2015-2016 wheat growing season (from 26 October, 2015 to 1 June, 2016). Each cultivar was planted in 10 rows (each row $2 \mathrm{~m}$ long, with 20 plants per line). At maturity, 15 spikes were stochastically collected from each row to measure the grain $\mathrm{Cd}$ concentration.

\section{Pot experiment}

To reveal the physiological mechanisms of grain $\mathrm{Cd}$ accumulation in open-air grown wheat plants under low$\mathrm{Cd}$ (Cd concentration, $0.4 \mathrm{mg} / \mathrm{kg}$ soil) stress and high-Cd (Cd concentration, $4 \mathrm{mg} / \mathrm{kg}$ soil) stresses, the five selected wheat cultivars were grown in pots at the Wenjiang experimental field (the elements concentration of soil were showed in STable 1) in the 2016-2017 wheat growing season at Sichuan Agricultural University as described above. Seeds of the wheat cultivars were sterilized with $5 \%$ N $\mathrm{NaClO}$ for $10 \mathrm{~min}$, washed three times with distilled water, and then allowed to imbibe in deionized water for $24 \mathrm{~h}$. They were then left to germinate at $20{ }^{\circ} \mathrm{C}$ for 6 days. Six seedlings were grown in each pot filled with $6.5 \mathrm{~kg}$ soil, which had been mixed with $\mathrm{CdCl}_{2}$ solution to give a final Cd concentration of $4 \mathrm{mg} / \mathrm{kg}$. There were 10 pots of each cultivar. At the seedling stage, three seedlings per pot were randomly harvested and divided into roots and shoots. At maturity, all plants were collected and divided into eight parts as described above, then dried at $80^{\circ} \mathrm{C}$ before determining the $\mathrm{Cd}$ concentration. 
The Cd concentration was determined as described in previous studies (Wang et al., 2014; Cheng et al., 2018). Briefly, each sample ( $0.20 \mathrm{~g}$ powder) was digested with a mixed acid solution $\left[\mathrm{HNO}_{3} / \mathrm{HClO}_{4}(v / v=4 / 1)\right]$ at 280 ${ }^{\circ} \mathrm{C}$ for $4 \mathrm{~h}$, then sequentially diluted to $50 \mathrm{~mL}$ with deionized water, and then filtered through filter paper. The $\mathrm{Cd}$ concentration was determined using an inductively coupled plasma mass spectrometer (ICP-MS, 7900; Agilent, Palo Alto, CA, USA). The Cd reference standard solution was purchased from the Guobiao Testing and Certification Company (Beijing, China).

The $\mathrm{Cd}$ concentrations in roots and shoots represented the $\mathrm{Cd}$ accumulation of the roots and shoot parts, respectively; the ratio of shoot $\mathrm{Cd}$ concentration to root $\mathrm{Cd}$ concentration (translocation factor, TF) represented the $\mathrm{Cd}$ translocated from roots to shoots; the ratio of grain $\mathrm{Cd}$ concentration to each shoot part Cd concentration (redistribution factor, RF) represented the $\mathrm{Cd}$ translocation from different shoot parts to grain (Yan et al., 2010, Shi et al., 2015).

\section{Statistical analyses}

Data means \pm standard deviation was obtained from three independent biological replicates. One-way analyses of variance (ANOVA) were carried out with SPSS software (version 20.0 for windows; IBM Japan Ltd., Tokyo, Japan). The normal distribution and the homogeneity of variance test of all raw observations were determined using Shapiro-Wilk test and one-way ANOVA test, respectively. When all data passed the normal distribution and the homogeneity of variance test, the differences of data among the treatments were then further analyzed using Duncan's test $(P \leq 0.05)$. Pearson Correlation was used to analyze the correlations among the treatments $(P \leq 0.05$ and $P \leq 0.01)$. All diagrams were constructed using SigmaPlot (version 12.0, Systat Software Inc. San Jose, CA).

\section{Results}

\section{Differences in grain Cd concentrations among wheat cultivars}

The Cd concentrations in seeds were determined for 46 wheat cultivars collected from Wenjiang and Shifang in the 2015-2016 wheat growing season. Their grain Cd concentrations ranged from 0.09 to $0.34 \mu \mathrm{g} / \mathrm{g}$ (average, $0.18 \pm 0.06 \mu \mathrm{g} / \mathrm{g}$ ) in Wenjiang and from 0.08 to $0.38 \mu \mathrm{g} / \mathrm{g}$ (average, $0.13 \pm 0.05 \mu \mathrm{g} / \mathrm{g}$ ) in Shifang. Of the 46 cultivars, 15 accumulated more than $0.20 \mu \mathrm{g} / \mathrm{g}$ Cd in the grain in Wenjiang, but only three accumulated $\mathrm{Cd}$ to this level in Shifang (Fig. 1). Twelve cultivars showed similar grain Cd concentrations between Wenjiang and Shifang, and 31 cultivars had significantly higher grain Cd concentrations in Wenjiang than in Shifang; only three cultivars had higher grain Cd concentrations in Shifang than in Wenjiang (Fig. 1). There was a significant correlation $\left(r^{2}=0.457, n=46\right)$ between grain Cd concentrations in Wenjiang and Shifang (Fig. 1).

According to the grain Cd concentrations of each cultivar in Wenjiang and Shifang, we selected five cultivars to explore the physiological mechanisms of grain $\mathrm{Cd}$ accumulation. The five cultivars comprised three low-Cd accumulators, YM51, YM53, and SM969 (average grain Cd concentrations of $0.09 \pm 0.01 \mu \mathrm{g} / \mathrm{g}, 0.15 \pm$ $0.02 \mu \mathrm{g} / \mathrm{g}$, and $0.15 \pm 0.05 \mu \mathrm{g} / \mathrm{g}$, respectively); one high-Cd accumulator, ZM18 (average grain Cd concentration, $0.35 \pm 0.08 \mu \mathrm{g} / \mathrm{g}$ ); and one variable-Cd accumulator, CM104 (average grain Cd concentrations of $0.19 \pm 0.01 \mu \mathrm{g} / \mathrm{g}$ in Wenjiang and $0.34 \pm 0.05 \mu \mathrm{g} / \mathrm{g}$ in Shifang). 


\section{Cd concentrations in different tissues, and TFs and RFs in wheat under low-Cd stress}

To understand the physiological mechanisms of grain $\mathrm{Cd}$ accumulation under low-Cd stress, we investigated the $\mathrm{Cd}$ concentrations in various tissues, and calculated the TFs and/or the RFs at the seedling and maturity stages of wheat cultivars under open-air condition. At the seedling stage, the $\mathrm{Cd}$ concentrations in the roots and shoots were similar between SM969 and ZM18, but were significantly higher than the other cultivars. Although the Cd concentrations in roots were similar among YM51, YM53 and CM104, the Cd concentrations in shoots differed among cultivars (YM51 > YM53 > CM104) (Table 1). However, their TFs were similar (Table 1). Correlation analyses showed that the $\mathrm{Cd}$ concentration in grain was not correlated with the $\mathrm{Cd}$ concentrations in roots and shoots or with the TF at the seedling stage (STable 2).

Table 1

Cd concentration and translocation factors (TFs) at the seedling stage.

\begin{tabular}{|c|c|c|c|c|c|c|c|}
\hline \multirow[t]{2}{*}{ Treatmen } & & \multirow[t]{2}{*}{ Tissues } & \multicolumn{5}{|c|}{ Wheat cultivars } \\
\hline & & & YM51 & YM53 & SM969 & ZM18 & CM104 \\
\hline \multirow[t]{3}{*}{$\begin{array}{l}\text { Low-Cd } \\
\text { stress }\end{array}$} & \multirow{2}{*}{$\begin{array}{l}\text { Cd concentration } \\
\left(\mu \mathrm{g} \mathrm{g}^{-1}\right) \mathrm{DW}\end{array}$} & Root & $\begin{array}{l}0.40 \pm \\
0.09 b\end{array}$ & $\begin{array}{l}0.39 \pm \\
0.03 \mathrm{~b}\end{array}$ & $\begin{array}{l}0.52 \pm \\
0.05 a\end{array}$ & $\begin{array}{l}0.52 \pm \\
0.08 a\end{array}$ & $\begin{array}{l}0.31 \pm \\
0.03 \mathrm{~b}\end{array}$ \\
\hline & & Shoot & $\begin{array}{l}0.21 \pm \\
0.01 \mathrm{~b}\end{array}$ & $\begin{array}{l}0.19 \pm \\
0.01 \mathrm{c}\end{array}$ & $\begin{array}{l}0.23 \pm \\
0.01 \mathrm{a}\end{array}$ & $\begin{array}{l}0.26 \pm \\
0.04 a\end{array}$ & $\begin{array}{l}0.17 \pm \\
0.02 \mathrm{~d}\end{array}$ \\
\hline & $\mathrm{CdTF}$ & $\begin{array}{l}\text { Root-to- } \\
\text { shoot }\end{array}$ & $\begin{array}{l}0.50 \pm \\
0.10 a\end{array}$ & $\begin{array}{l}0.47 \pm \\
0.01 \mathrm{a}\end{array}$ & $\begin{array}{l}0.45 \pm \\
0.05 a\end{array}$ & $\begin{array}{l}0.51 \pm \\
0.15 a\end{array}$ & $\begin{array}{l}0.56 \pm \\
0.11 \mathrm{a}\end{array}$ \\
\hline \multirow[t]{3}{*}{$\begin{array}{l}\text { High-Cd } \\
\text { stress }\end{array}$} & \multirow[t]{2}{*}{$\begin{array}{l}\text { Cd concentration } \\
\left(\mu \mathrm{g} \mathrm{g}^{-1}\right) \mathrm{DW}\end{array}$} & Root & $\begin{array}{l}24.48 \pm \\
3.49 \mathrm{~b}\end{array}$ & $\begin{array}{l}52.19 \pm \\
7.78 a\end{array}$ & $\begin{array}{l}22.61 \pm \\
0.89 \mathrm{~b}\end{array}$ & $\begin{array}{l}14.71 \pm \\
0.15 c\end{array}$ & $\begin{array}{l}17.35 \pm \\
0.75 \mathrm{c}\end{array}$ \\
\hline & & Shoot & $\begin{array}{l}6.61 \pm \\
0.57 \mathrm{~b}\end{array}$ & $\begin{array}{l}11.87 \pm \\
1.43 a\end{array}$ & $\begin{array}{l}4.94 \pm \\
0.27 \mathrm{bc}\end{array}$ & $\begin{array}{l}6.37 \pm \\
1.02 \mathrm{~b}\end{array}$ & $\begin{array}{l}4.13 \pm \\
0.64 c\end{array}$ \\
\hline & $\mathrm{CdTF}$ & $\begin{array}{l}\text { Root-to- } \\
\text { shoot }\end{array}$ & $\begin{array}{l}0.27 \pm \\
0.04 \mathrm{~b}\end{array}$ & $\begin{array}{l}0.23 \pm \\
0.06 \mathrm{~b}\end{array}$ & $\begin{array}{l}0.22 \pm \\
0.01 \mathrm{~b}\end{array}$ & $\begin{array}{l}0.43 \pm \\
0.07 a\end{array}$ & $\begin{array}{l}0.24 \pm \\
0.04 \mathrm{~b}\end{array}$ \\
\hline
\end{tabular}

At the mature stage, ZM18 accumulated the highest Cd concentration in the grain among all five cultivars (Fig. 2A). Thus, ZM18 served as the high-Cd accumulator in this study to understand the physiological mechanisms of grain $\mathrm{Cd}$ accumulation. The $\mathrm{Cd}$ concentrations in roots and lower stems did not differ significantly among the five cultivars (Fig. 2B and 2C). The Cd concentrations in older leaves were similar among YM53, SM969, and ZM18, and were noticeably lower than those in YM51 and CM104 (Fig. 2D). In flag leaves, the Cd concentration was only higher in CM104 than in ZM18 (Fig. 2E). In internode 1, the Cd concentration was significantly lower in YM51 than in ZM18 (Fig. 2F). The Cd concentrations in the rachis were significantly lower in YM51 and SM969 than in ZM18; and were also lower in YM53 and CM104 than in ZM18, but those differences were not significant (Fig. 2G). For glumes, although the $\mathrm{Cd}$ concentrations were lower in YM51, YM53, SM969, and CM104 than in ZM18, the difference was only significant for SM969 (Fig. $2 \mathrm{H}$ ). Correlation analyses indicated that the $\mathrm{Cd}$ concentration in grain was significantly positively correlated with the Cd concentrations in the glumes and rachis (Table 4). 
Table 4

Correlation analyses between Cd concentration in grain with Cd concentrations, TFs and RFs in different tissues at the maturity stage, respectively.

\begin{tabular}{|c|c|c|c|}
\hline & Correlations & $\begin{array}{l}\text { Low-Cd } \\
\text { stress }\end{array}$ & $\begin{array}{l}\text { High-Cd } \\
\text { stress }\end{array}$ \\
\hline & & \multicolumn{2}{|c|}{ Cd concentration in grain } \\
\hline \multirow{7}{*}{$\begin{array}{l}\text { Cd concentrations at the mature } \\
\text { stage }\end{array}$} & Cd concentration in roots & 0.006 & $0.815^{\star \star}$ \\
\hline & $\begin{array}{l}\text { Cd concentration in lower } \\
\text { stems }\end{array}$ & -0.241 & $0.854^{\star \star}$ \\
\hline & $\begin{array}{l}\text { Cd concentration in older } \\
\text { leaves }\end{array}$ & -0.411 & 0.720 ** \\
\hline & Cd concentration in internode 1 & 0.342 & $0.967^{\star \star}$ \\
\hline & Cd concentration in flag leaves & -0.251 & $0.945^{\star \star}$ \\
\hline & Cd concentration in rachis & $0.626^{*}$ & $0.913^{\star \star}$ \\
\hline & Cd concentration in glumes & $0.580 *$ & $0.862^{\star \star}$ \\
\hline \multirow[t]{8}{*}{ Cd TFs at the mature stage } & Cd TF of roots to lower stems & -0.200 & 0.386 \\
\hline & Cd TF of roots to older leaves & -0.422 & 0.297 \\
\hline & Cd TF of roots to internode 1 & 0.132 & $0.594^{\star}$ \\
\hline & Cd TF of roots to flag leaves & -0.261 & $0.613^{*}$ \\
\hline & Cd TF of roots to rachis & 0.376 & $0.560 *$ \\
\hline & Cd TF of roots to glumes & 0.177 & 0.153 \\
\hline & Cd TF of roots to grains & $0.819 * \star$ & $0.518^{*}$ \\
\hline & Cd TF of roots to total shoots & 0.125 & 0.465 \\
\hline \multirow[t]{6}{*}{ Cd RFs at the mature stage } & Cd RF of lower stems to grains & $0.869 * *$ & 0.104 \\
\hline & Cd RF of older leaves to grains & $0.838 * \star$ & 0.099 \\
\hline & Cd RF of internode 1 to grains & $0.821^{\star \star}$ & -0.207 \\
\hline & Cd RF of flag leaves to grains & $0.839 * *$ & -0.219 \\
\hline & Cd RF of rachis to grains & $0.571^{*}$ & -0.075 \\
\hline & Cd RF of glumes to grains & 0.926 ** & 0.474 \\
\hline
\end{tabular}

To evaluate Cd translocation from roots to shoot parts, the TFs were calculated (Table 2). There was no significant difference among the five cultivars in the TFs of roots to total shoots, roots to lower stems, roots to internode 1, roots to rachis, and roots to glumes. The TFs of roots to older leaves and roots to flag leaves were higher in CM104 than in ZM18. The TFs of roots to older leaves and roots to flag leaves were similar in YM51, YM53, SM969, and ZM18. For roots to grain, the TFs were significantly lower in YM51 and CM104 than in 
ZM18. The Cd concentration in grain was significantly positively correlated with the TFs of roots to grain. The Cd concentration in grain was negatively correlated with the TFs of roots to flag leaves, roots to older leaves, and roots to lower stems, but the correlation coefficients were not significant (Table 4).

Table 2

Cd translocation factors (TFs) from roots to shoot parts at the maturity stage.

\begin{tabular}{|c|c|c|c|c|c|c|c|c|c|}
\hline \multirow[t]{2}{*}{ Treatments } & \multicolumn{9}{|c|}{ Cd TFs from roots to shoot parts } \\
\hline & $\begin{array}{l}\text { Wheat } \\
\text { cultivars }\end{array}$ & $\begin{array}{l}\text { Roots } \\
\text { to } \\
\text { lower } \\
\text { stems }\end{array}$ & $\begin{array}{l}\text { Roots to } \\
\text { Internode } \\
1\end{array}$ & $\begin{array}{l}\text { Roots } \\
\text { to } \\
\text { older } \\
\text { leaves }\end{array}$ & $\begin{array}{l}\text { Roots } \\
\text { to flag } \\
\text { leaves }\end{array}$ & $\begin{array}{l}\text { Roots } \\
\text { to } \\
\text { rachis }\end{array}$ & $\begin{array}{l}\text { Roots } \\
\text { to } \\
\text { glumes }\end{array}$ & $\begin{array}{l}\text { Roots } \\
\text { to } \\
\text { grains }\end{array}$ & $\begin{array}{l}\text { Roots } \\
\text { to } \\
\text { total } \\
\text { shoots }\end{array}$ \\
\hline \multirow[t]{5}{*}{$\begin{array}{l}\text { Low-Cd } \\
\text { stress }\end{array}$} & YM51 & $\begin{array}{l}0.20 \\
\pm \\
0.03 a\end{array}$ & $\begin{array}{l}0.27 \pm \\
0.10 a\end{array}$ & $\begin{array}{l}0.78 \pm \\
0.11 a b\end{array}$ & $\begin{array}{l}0.88 \\
\pm \\
0.24 \mathrm{~b}\end{array}$ & $\begin{array}{l}0.21 \\
\pm \\
0.07 a\end{array}$ & $\begin{array}{l}0.26 \pm \\
0.08 a\end{array}$ & $\begin{array}{l}0.70 \pm \\
0.16 \mathrm{~b}\end{array}$ & $\begin{array}{l}3.29 \pm \\
0.65 a\end{array}$ \\
\hline & YM53 & $\begin{array}{l}0.21 \\
\pm \\
0.07 a\end{array}$ & $\begin{array}{l}0.32 \pm \\
0.09 a\end{array}$ & $\begin{array}{l}0.56 \pm \\
0.18 \mathrm{bc}\end{array}$ & $\begin{array}{l}0.89 \\
\pm \\
0.27 \mathrm{~b}\end{array}$ & $\begin{array}{l}0.27 \\
\pm \\
0.08 a\end{array}$ & $\begin{array}{l}0.28 \pm \\
0.06 a\end{array}$ & $\begin{array}{l}0.98 \pm \\
0.26 \mathrm{ab}\end{array}$ & $\begin{array}{l}3.52 \pm \\
0.93 a\end{array}$ \\
\hline & SM969 & $\begin{array}{l}0.19 \\
\pm \\
0.05 a\end{array}$ & $\begin{array}{l}0.33 \pm \\
0.06 a\end{array}$ & $\begin{array}{l}0.44 \pm \\
0.08 \mathrm{c}\end{array}$ & $\begin{array}{l}0.77 \\
\pm \\
0.17 \mathrm{~b}\end{array}$ & $\begin{array}{l}0.21 \\
\pm \\
0.04 a\end{array}$ & $\begin{array}{l}0.26 \pm \\
0.08 a\end{array}$ & $\begin{array}{l}0.90 \pm \\
0.30 \mathrm{ab}\end{array}$ & $\begin{array}{l}3.18 \pm \\
0.75 a\end{array}$ \\
\hline & ZM18 & $\begin{array}{l}0.18 \\
\pm \\
0.04 a\end{array}$ & $\begin{array}{l}0.35 \pm \\
0.06 a\end{array}$ & $\begin{array}{l}0.52 \pm \\
0.13 \mathrm{bc}\end{array}$ & $\begin{array}{l}0.87 \\
\pm \\
0.18 \mathrm{~b}\end{array}$ & $\begin{array}{l}0.32 \\
\pm \\
0.07 a\end{array}$ & $\begin{array}{l}0.30 \pm \\
0.06 a\end{array}$ & $\begin{array}{l}1.25 \pm \\
0.26 a\end{array}$ & $\begin{array}{l}3.80 \pm \\
0.78 a\end{array}$ \\
\hline & CM104 & $\begin{array}{l}0.25 \\
\pm \\
0.08 a\end{array}$ & $\begin{array}{l}0.38 \pm \\
0.03 a\end{array}$ & $\begin{array}{l}0.87 \pm \\
0.06 a\end{array}$ & $\begin{array}{l}1.46 \\
\pm \\
0.14 a\end{array}$ & $\begin{array}{l}0.27 \\
\pm \\
0.08 a\end{array}$ & $\begin{array}{l}0.31 \pm \\
0.03 a\end{array}$ & $\begin{array}{l}0.84 \pm \\
0.03 \mathrm{~b}\end{array}$ & $\begin{array}{l}4.37 \pm \\
0.32 \mathrm{a}\end{array}$ \\
\hline \multirow[t]{5}{*}{$\begin{array}{l}\text { High-Cd } \\
\text { stress }\end{array}$} & YM51 & $\begin{array}{l}0.09 \\
\pm \\
0.00 \mathrm{a}\end{array}$ & $\begin{array}{l}0.17 \pm \\
0.06 a\end{array}$ & $\begin{array}{l}0.33 \pm \\
0.02 \mathrm{~b}\end{array}$ & $\begin{array}{l}0.09 \\
\pm \\
0.00 \mathrm{a}\end{array}$ & $\begin{array}{l}0.19 \\
\pm \\
0.03 \mathrm{~b}\end{array}$ & $\begin{array}{l}0.20 \pm \\
0.01 \mathrm{a}\end{array}$ & $\begin{array}{l}0.11 \pm \\
0.00 a\end{array}$ & $\begin{array}{l}1.19 \pm \\
0.01 \mathrm{a}\end{array}$ \\
\hline & YM53 & $\begin{array}{l}0.11 \\
\pm \\
0.04 a\end{array}$ & $\begin{array}{l}0.21 \pm \\
0.07 a\end{array}$ & $\begin{array}{l}0.34 \pm \\
0.11 \mathrm{~b}\end{array}$ & $\begin{array}{l}0.11 \\
\pm \\
0.04 a\end{array}$ & $\begin{array}{l}0.19 \\
\pm \\
0.01 \mathrm{~b}\end{array}$ & $\begin{array}{l}0.25 \pm \\
0.09 a\end{array}$ & $\begin{array}{l}0.14 \pm \\
0.04 a\end{array}$ & $\begin{array}{l}1.35 \pm \\
0.40 a\end{array}$ \\
\hline & SM969 & $\begin{array}{l}0.16 \\
\pm \\
0.10 a\end{array}$ & $\begin{array}{l}0.24 \pm \\
0.01 a\end{array}$ & $\begin{array}{l}0.72 \pm \\
0.04 a\end{array}$ & $\begin{array}{l}0.14 \\
\pm \\
0.01 a\end{array}$ & $\begin{array}{l}0.21 \\
\pm \\
0.01 \mathrm{~b}\end{array}$ & $\begin{array}{l}0.17 \pm \\
0.02 a\end{array}$ & $\begin{array}{l}0.13 \pm \\
0.01 a\end{array}$ & $\begin{array}{l}1.78 \pm \\
0.05 a\end{array}$ \\
\hline & ZM18 & $\begin{array}{l}0.15 \\
\pm \\
0.04 a\end{array}$ & $\begin{array}{l}0.25 \pm \\
0.06 a\end{array}$ & $\begin{array}{l}0.60 \pm \\
0.14 a\end{array}$ & $\begin{array}{l}0.13 \\
\pm \\
0.03 a\end{array}$ & $\begin{array}{l}0.28 \\
\pm \\
0.05 a\end{array}$ & $\begin{array}{l}0.29 \pm \\
0.07 a\end{array}$ & $\begin{array}{l}0.16 \pm \\
0.04 a\end{array}$ & $\begin{array}{l}1.86 \pm \\
0.43 a\end{array}$ \\
\hline & CM104 & $\begin{array}{l}0.13 \\
\pm \\
0.00 a\end{array}$ & $\begin{array}{l}0.18 \pm \\
0.00 a\end{array}$ & $\begin{array}{l}0.59 \pm \\
0.02 \mathrm{a}\end{array}$ & $\begin{array}{l}0.10 \\
\pm \\
0.00 a\end{array}$ & $\begin{array}{l}0.16 \\
\pm \\
0.01 \mathrm{~b}\end{array}$ & $\begin{array}{l}0.23 \pm \\
0.00 a\end{array}$ & $\begin{array}{l}0.12 \pm \\
0.01 a\end{array}$ & $\begin{array}{l}1.51 \pm \\
0.04 a\end{array}$ \\
\hline
\end{tabular}

To analyze Cd redistribution from shoot parts to grain, we calculated RF values (Table 3). The RFs from lower stems and older leaves to grain were significantly lower in YM51, YM53, SM969, and CM104 than in ZM18. For glumes to grain and flag leaves to grain, the RFs were significantly lower in YM51 and CM104 than in ZM18; but were not significantly lower in YM53 and SM969 than in ZM18. The RFs from internode 1 to grain 
and rachis 1 to grain did not differ significantly among the five cultivars. Correlation analyses showed that the Cd concentration in grain was significantly positively correlated with the RFs of all shoot parts to grain. Among them, the highest correlation coefficient was for glumes to grain, and the lowest correlation coefficient was for rachis to grain (Table 4).

Table 3

Cd redistribution factors (RFs) from shoot parts to grains at the maturity stage.

\begin{tabular}{|c|c|c|c|c|c|c|c|}
\hline \multirow[t]{2}{*}{ Treatments } & \multirow{2}{*}{$\begin{array}{l}\text { Wheat } \\
\text { cultivars }\end{array}$} & \multicolumn{6}{|c|}{ Cd RFs from shoot parts to grains } \\
\hline & & $\begin{array}{l}\text { Glumes } \\
\text { to grains }\end{array}$ & $\begin{array}{l}\text { Rachis } \\
\text { to } \\
\text { grains }\end{array}$ & $\begin{array}{l}\text { Internode } \\
1 \text { to grains }\end{array}$ & $\begin{array}{l}\text { Flag } \\
\text { leaves to } \\
\text { grains }\end{array}$ & $\begin{array}{l}\text { Lower } \\
\text { stems to } \\
\text { grains }\end{array}$ & $\begin{array}{l}\text { Older } \\
\text { leaves to } \\
\text { grains }\end{array}$ \\
\hline \multirow[t]{5}{*}{$\begin{array}{l}\text { Low-Cd } \\
\text { stress }\end{array}$} & YM51 & $\begin{array}{l}2.71 \pm \\
0.71 \mathrm{~b}\end{array}$ & $\begin{array}{l}3.42 \pm \\
1.08 a\end{array}$ & $\begin{array}{l}2.76 \pm \\
0.84 a\end{array}$ & $\begin{array}{l}0.81 \pm \\
0.23 \mathrm{bc}\end{array}$ & $\begin{array}{l}3.44 \pm \\
0.77 \mathrm{~b}\end{array}$ & $\begin{array}{l}0.89 \pm \\
0.15 c\end{array}$ \\
\hline & YM53 & $\begin{array}{l}3.52 \pm \\
0.28 \mathrm{~b}\end{array}$ & $\begin{array}{l}3.60 \pm \\
0.18 \mathrm{a}\end{array}$ & $\begin{array}{l}3.06 \pm \\
0.35 a\end{array}$ & $\begin{array}{l}1.11 \pm \\
0.24 \mathrm{ab}\end{array}$ & $\begin{array}{l}4.68 \pm \\
0.70 \mathrm{~b}\end{array}$ & $\begin{array}{l}1.76 \pm \\
0.09 \mathrm{~b}\end{array}$ \\
\hline & SM969 & $\begin{array}{l}3.41 \pm \\
0.22 \mathrm{~b}\end{array}$ & $\begin{array}{l}4.16 \pm \\
1.07 a\end{array}$ & $\begin{array}{l}2.68 \pm \\
0.74 a\end{array}$ & $\begin{array}{l}1.14 \pm \\
0.19 \mathrm{ab}\end{array}$ & $\begin{array}{l}4.82 \pm \\
1.18 \mathrm{~b}\end{array}$ & $\begin{array}{l}2.00 \pm \\
0.44 \mathrm{~b}\end{array}$ \\
\hline & ZM18 & $\begin{array}{l}4.15 \pm \\
0.08 a\end{array}$ & $\begin{array}{l}3.92 \pm \\
0.28 a\end{array}$ & $\begin{array}{l}3.52 \pm \\
0.35 a\end{array}$ & $\begin{array}{l}1.45 \pm \\
0.04 a\end{array}$ & $\begin{array}{l}6.97 \pm \\
0.29 a\end{array}$ & $\begin{array}{l}2.42 \pm \\
0.12 \mathrm{a}\end{array}$ \\
\hline & CM104 & $\begin{array}{l}2.70 \pm \\
0.29 b\end{array}$ & $\begin{array}{l}3.33 \pm \\
0.91 \mathrm{a}\end{array}$ & $\begin{array}{l}2.22 \pm \\
0.23 a\end{array}$ & $\begin{array}{l}0.58 \pm \\
0.07 \mathrm{c}\end{array}$ & $\begin{array}{l}3.60 \pm \\
1.14 \mathrm{~b}\end{array}$ & $\begin{array}{l}0.97 \pm \\
0.10 c\end{array}$ \\
\hline \multirow[t]{5}{*}{$\begin{array}{l}\text { High-Cd } \\
\text { stress }\end{array}$} & YM51 & $\begin{array}{l}0.54 \pm \\
0.03 \mathrm{~b}\end{array}$ & $\begin{array}{l}0.57 \pm \\
0.07 a\end{array}$ & $\begin{array}{l}0.61 \pm \\
0.03 a\end{array}$ & $\begin{array}{l}1.14 \pm \\
0.06 a\end{array}$ & $\begin{array}{l}1.14 \pm \\
0.06 \mathrm{~b}\end{array}$ & $\begin{array}{l}0.32 \pm \\
0.02 b\end{array}$ \\
\hline & YM53 & $\begin{array}{l}0.54 \pm \\
0.01 \mathrm{~b}\end{array}$ & $\begin{array}{l}0.70 \pm \\
0.18 a\end{array}$ & $\begin{array}{l}0.64 \pm \\
0.01 \mathrm{a}\end{array}$ & $\begin{array}{l}1.21 \pm \\
0.02 a\end{array}$ & $\begin{array}{l}1.27 \pm \\
0.07 a\end{array}$ & $\begin{array}{l}0.40 \pm \\
0.00 a\end{array}$ \\
\hline & SM969 & $\begin{array}{l}0.77 \pm \\
0.18 a\end{array}$ & $\begin{array}{l}0.61 \pm \\
0.09 a\end{array}$ & $\begin{array}{l}0.53 \pm \\
0.02 \mathrm{~b}\end{array}$ & $\begin{array}{l}0.95 \pm \\
0.05 b\end{array}$ & $0.80 \pm 0.03 c$ & $\begin{array}{l}0.18 \pm \\
0.01 \mathrm{~d}\end{array}$ \\
\hline & ZM18 & $\begin{array}{l}0.54 \pm \\
0.01 \mathrm{~b}\end{array}$ & $\begin{array}{l}0.56 \pm \\
0.03 a\end{array}$ & $\begin{array}{l}0.64 \pm \\
0.01 \mathrm{a}\end{array}$ & $\begin{array}{l}1.21 \pm \\
0.01 \mathrm{a}\end{array}$ & $\begin{array}{l}1.07 \pm \\
0.08 \mathrm{~b}\end{array}$ & $\begin{array}{l}0.26 \pm \\
0.00 \mathrm{c}\end{array}$ \\
\hline & CM104 & $\begin{array}{l}0.50 \pm \\
0.04 \mathrm{~b}\end{array}$ & $\begin{array}{l}0.71 \pm \\
0.00 \mathrm{a}\end{array}$ & $\begin{array}{l}0.64 \pm \\
0.04 a\end{array}$ & $\begin{array}{l}1.21 \pm \\
0.11 \mathrm{a}\end{array}$ & $0.86 \pm 0.05 c$ & $\begin{array}{l}0.19 \pm \\
0.01 \mathrm{~d}\end{array}$ \\
\hline
\end{tabular}

\section{Cd concentrations in tissues, and TFs and RFs in wheat plants under high-Cd stress in the pot experiment}

Compared with low-Cd stress, high-Cd stress caused various changes in Cd accumulation, translocation, and redistribution. The $\mathrm{Cd}$ concentrations in the roots and shoots of YM53 were the highest at the seedling stage. The Cd concentrations in roots were significantly lower in ZM18 and CM104 than in YM51 and SM969. The Cd concentration in shoots was significantly lower in CM104 than in YM51, YM53, and ZM18 (Table 1). The TFs of YM51, YM53, SM969, and CM104 were similar, but were much lower than the TF of ZM18 (Table 1). 
At the mature stage, the highest Cd concentrations in grain were in YM53, SM969, and ZM18, and were much higher than those in YM51 and CM104 (Fig. 3A). Thus, ZM18 was selected as the high-Cd accumulator to analyze responses to high-Cd stress. Similar results were observed in the roots and rachis (Fig. 3B and 3C). For lower stems and older leaves, the Cd concentration in ZM18 was significantly lower than that in SM969, but much higher than that in YM51, YM53, and CM104 (Fig. 3D and 3E). Similar results were detected for flag leaves and internode 1, except in YM53, which had Cd concentrations similar to those in ZM18 (Fig. 3F and 3G). The Cd concentration in glumes was similar in YM53 and ZM18, and higher in those two cultivars than in YM51, SM969, and CM104 (Fig. 3H). Correlation analyses indicated that the Cd concentration in grain was significantly positively correlated with the Cd concentration in each tissue (Table 4).

There was no difference in the TFs of roots to total shoots, roots to lower stems, roots to internode 1, roots to flag leaves, roots to glumes, and roots to grain among the five cultivars (Table 2). For roots to rachis, the TFs of YM51, YM53, SM969, and CM104 were significantly lower than that of ZM18. The TFs of roots to older leaves were significantly lower in YM51 and YM53 than in ZM18. The Cd concentration in grain was significantly positively correlated with the TFs of roots to internode 1 , roots to flag leaves, roots to rachis, and roots to grain (Table 4).

The RF of rachis to grain did not differ significantly among the five cultivars (Table 3 ). The RF of glumes to grain was significantly higher in SM969 than in ZM18; and vice versa for the RFs of internode 1 to grain and flag leaves to grain. The RFs of glumes to grain, internode 1 to grain, and flag leaves to grain were similar among YM51, YM53, CM104, and ZM18. For lower stems to grain and older leaves to grain, the RFs of ZM18 were significantly lower than those of YM53 and YM51 (except the RF of lower stems to grain in YM51), but higher than those of SM969 and CM104. The grain Cd concentration was not correlated with any of the RFs (Table 4).

\section{Discussion}

\section{Cd concentration in grain differs among different genotypes of common wheat}

In this study, we found that the grain Cd concentrations varied among the 46 wheat cultivars grown in Wenjiang and Shifang, and the Cd concentrations were positively correlated between the two sites (Fig. 1). Similar results have also been reported for Japanese wheat cultivars (Kubo et al., 2008) and American winter wheat cultivars (Guttieri et al., 2015). These results indicate that the $\mathrm{Cd}$ concentration in grain differs among genotypes, and is controlled by genetic factors. Twelve cultivars accumulated similar grain $\mathrm{Cd}$ concentrations in Wenjiang and Shifang; of them, 10 cultivars accumulated Cd in the grain to concentrations of less than $0.15 \mu \mathrm{g} / \mathrm{g}$ (Fig. 1). Thus, low-Cd accumulating lines suitable for cultivation in multiple environments could be bred by genetic improvement. Of the 46 cultivars, 31 had significantly higher grain Cd concentrations in Wenjiang than in Shifang, which might because of the higher Cd concentration in soil of Wenjiang than Shifang (STable 3). These result indicates that the grain $\mathrm{Cd}$ accumulation is also affected by environmental conditions (Kubo et al., 2008; Guttieri et al., 2015), and could be significantly reduced by selecting suitable sites for crop cultivation (Grant et al., 2008; Liu et al., 2018). 


\section{Direct Cd transport from roots to grain and Cd redistribution from shoot parts to grain determines grain $\mathrm{Cd}$ accumulation under low-Cd stress}

In previous studies, the grain Cd concentration in bread wheat was found to be positively correlated with root $\mathrm{Cd}$ uptake and the $\mathrm{Cd}$ translocation from the roots to shoots at the seedling stage (Zhang et al., 2002; Greger and Löfstedt, 2004; Kubo et al., 2011). For durum wheat, rice, and soybean, the seed or grain Cd concentrations were found to be positively correlated with $\mathrm{Cd}$ translocation from the root to shoot, but not with root Cd uptake (Arao et al., 2002; Greger and Löfstedt, 2004; Ueno et al., 2010; Harris and Taylor, 2013; Arduini et al., 2014). In this study, although the Cd concentrations in roots and shoots at the seedling stage differed among the five selected cultivars (Table 1), the grain $\mathrm{Cd}$ concentration was not correlated with the Cd concentrations in roots and shoots, or with the TF from root to shoot (STable 2). These different findings may result from the different genetic background of wheat.

A study on durum wheat found that genetic variation in $\mathrm{Cd}$ translocation from roots to shoots accounted for $80-90 \%$ of phenotypic variation in grain Cd accumulation, and that this is controlled by a single locus (Cdu 1) (Wiebe et al., 2010; Pozniak et al., 2012; Harris and Taylor, 2013). Common wheat lacks the Cdu1 locus and possesses various mechanisms of grain Cd accumulation. In this study, the grain Cd concentration was not significantly correlated with the TFs of roots to glumes, roots to older leaves, roots to flag leaves, roots to lower stems, roots to internode 1, or roots to rachis (Table 4). Thus, grain Cd accumulation in these cultivars did not result from Cd translocation from roots to shoot parts (Shi et al., 2015). However, the grain Cd concentration was correlated with the $\mathrm{Cd}$ concentrations in the glumes and rachis (Table 4), the TF of roots to grain (Table 4), and all the RFs (Table 4) at the mature stage under low-Cd stress. These results clearly indicate that in these cultivars of common wheat, grain $\mathrm{Cd}$ accumulation resulted from the direct Cd transport from roots to grain and the redistribution of $\mathrm{Cd}$ from shoot parts to grain.

The Cd concentrations in roots were similar among the five cultivars (Fig. 2B), and there was no significant correlation between root $\mathrm{Cd}$ concentration and grain $\mathrm{Cd}$ concentration (Table 4). Thus, in these cultivars, the $\mathrm{Cd}$ in grain resulted from direct $\mathrm{Cd}$ transport from roots to grain and was not affected by Cd accumulation in the roots, which supports the results of Kubo et al. (2011) and Liang et al. (2017). Although the TF of roots to grain in ZM18 was significantly higher than those in YM51 and CM104, it was not significantly different from those in YM53 and SM969 (Table 2). Thus, compared with the high-Cd accumulator ZM18, the low level of direct $\mathrm{Cd}$ transport from roots to grain contributed to the low grain Cd concentrations in YM51 and CM104; however for YM53, SM969, the direct Cd transport from roots to grain had a small effect on grain Cd concentration, but not a large effect as reported by Kubo et al. (2016).

In rice, half of the $\mathrm{Cd}$ in grain is derived from Cd redistribution from shoots to grain (Rodda et al., 2011), and there are differences in Cd redistribution between high- and low-Cd accumulating genotypes (Liu et al., 2007). In previous of five wheat cultivars, the $\mathrm{Cd}$ remobilized from leaves and stems to grain contributed to $\mathrm{Cd}$ accumulation in the grain (Harris and Taylor, 2001; Greger and Löfstedt, 2004; Chan and Hale, 2004; Kubo et al., 2016). Our results indicated that differences in $\mathrm{Cd}$ redistribution from all shoot parts to grain resulted in differences in grain Cd concentrations among cultivars. ZM18, a high-Cd accumulating cultivar, had the 
highest RFs of all shoot parts to grain (except for rachis to grain) (Table 3), indicating that the high grain Cd concentration resulted from high Cd redistribution from shoots to grain. Compared with ZM18, YM53 and SM969 had lower RFs for lower stems to grain and older leaves to grain (Table 3). These results indicate that Cd was retained in the lower stems and older leaves in YM53 and SM969, ultimately resulting in their low grain $\mathrm{Cd}$ concentrations. The five cultivars showed differences in the contribution of Cd remobilized from stems to grain (Shi et al., 2019). However, the Cd concentrations in older leaves and lower stems were similar among YM53, SM969, and ZM18 (Fig. 2C and 2D), suggesting that these three cultivars had similar capacities for Cd sequestration in these parts. For YM51 and CM104, the RFs of glumes to grain, flag leaves to grain, lower stems to grain and older leaves to grain were significantly lower than those of ZM18 (Table 3), suggesting that the low grain $\mathrm{Cd}$ concentrations in these cultivars were resulted from retention of $\mathrm{Cd}$ in the glumes, flag leaves, lower stems, and older leaves. Thus, Cd retention by these four tissues could explain the differences in grain Cd concentrations between ZM18, YM51, and CM104. The highest Cd concentration in older leaves was detected in YM51 and CM104 (Fig. 2D); while the highest Cd concentration in flag leaves was detected in CM104 (Fig. 2E). These results indicate that the capacities of Cd sequestration differ between older leaves and flag leaves. Heavy metals are transported to leaves and remobilized from leaves via the phloem in a process regulated by metal transporters such as OsYSL2, OsLCT, OsNRAMP3 (Koike et al., 2004; Yoneyama et al., 2010; Uraguchi and Fujiwara, 2012; Yamaji et al., 2013). Thus, there may be different metal transporters regulating Cd transport and/or redistribution to/from older leaves and flag leaves between YM51 and CM104.

Additionally, although $\mathrm{Cd}$ redistribution from glumes and the rachis to grain contributed to $\mathrm{Cd}$ in the grain, it could not explain differences in grain Cd concentrations among these cultivars. Other studies have reported that $\mathrm{Cd}$ redistribution from the rachis and glumes can explain differences in grain $\mathrm{Cd}$ accumulation (Shi et al., 2015; Kubo et al., 2016). The differences in results between our study and those of Shi et al. (2015) and Kubo et al. (2016) may be related to different wheat genotypes and soil conditions.

\section{Cd concentration in each tissue, and $\mathrm{Cd}$ translocation from roots to above-ground parts determine grain $\mathrm{Cd}$ accumulation under high-Cd stress}

The uptake and translocation of $\mathrm{Cd}$ by plants are dependent on the Cd concentration in soil. Under high-Cd stress, ZM18, YM53, and SM969 accumulated significantly higher Cd concentration in grain than that of YM51 and CM104 (Fig. 3A). The Cd concentrations in all tissues except for older leaves were higher in YM53, SM969, and ZM18 than in YM51 and CM104 (Fig. 3). These results indicate that high-Cd stress changed the accumulation and the partitioning of $\mathrm{Cd}$ in the five cultivars.

In a previous study, which the wheat plants treated with $13.70 \mathrm{mg} / \mathrm{kg} \mathrm{Cd}$ (a much higher dose than that used in our study, the wheat grain $\mathrm{Cd}$ concentration was found to be positively correlated with the root $\mathrm{Cd}$ concentration, and Cd redistribution from shoots to grain (Shi et al., 2015). In our study, correlation analyses indicated that the grain $\mathrm{Cd}$ concentration was positively correlated with the $\mathrm{Cd}$ concentration in each tissue (Table 4), and with the TFs of roots to grain, flag leaves, internode 1 and rachis (Table 4), but not with the RFs (Table 4). Thus, the $\mathrm{Cd}$ concentration in each tissue, and the $\mathrm{Cd}$ translocation from roots to grain, roots to flag leaves, roots to internode 1 , and roots to rachis determined the grain $\mathrm{Cd}$ accumulation under high-Cd stress. 
In rice and soybean, the $\mathrm{Cd}$ concentration in grain/seeds was found to be negatively correlated with the Cd concentration in roots, but positively correlated with the $\mathrm{Cd}$ concentration in shoots, and Cd retention in roots limited Cd translocation to shoots (Ueno et al., 2010; Wang et al., 2018). The Cd concentrations in roots and shoot parts are mainly determined by the $\mathrm{Cd}$ uptake and retention in roots, and the ability of $\mathrm{Cd}$ translocation from roots to the shoots. In our study, we found that the TFs did not differ significantly among these five cultivars (except for the TFs of roots to older leaves and roots to rachis) (Table 2), indicating that the abilities of roots to retain $\mathrm{Cd}$ and to translocate $\mathrm{Cd}$ to the shoots were similar among the five cultivars. Thus, the higher Cd concentrations in all tissues (except for grain) of YM53, SM969 and ZM18 indicated that the Cd uptake abilities of YM53, SM969, and ZM18 were significantly higher than those of YM51 and CM104, resulting in their different grain Cd concentrations.

In cereals, the rachis serves as a switch for Cd transport from internode 1 to grain (Shi et al., 2015). The flag leaf connects with internode 1 and the rachis via the uppermost node. The Cd loaded from the xylem to the nodes can be transferred to the phloem. The accumulation of $\mathrm{Cd}$ in leaves and grain is dependent on phloem transport (Chen et al., 2007; Kobayashi et al., 2013; Kubo et al., 2016). In this study, the Cd translocation from roots to grain, roots to flag leaves, roots to internode 1 , and roots to rachis determined the grain $\mathrm{Cd}$ accumulation, but could not explain differences in grain $\mathrm{Cd}$ concentrations among cultivars under high-Cd stress because their TFs were similar (Table 2). In addition, Cd redistribution from these tissues to grain was not correlated with the grain $\mathrm{Cd}$ concentration (Table 4). Thus, in these five wheat cultivars, the $\mathrm{Cd}$ taken up by roots was synchronously transported to new shoots, and the amount taken up was determined by the Cduptake ability of the roots.

\section{Conclusions}

The results of this study were showed as Fig. 4.

(1) Under low-Cd stress, the grains Cd accumulation in common wheat was strongly affected by the direct transport of $\mathrm{Cd}$ from roots to grains, and the redistribution of $\mathrm{Cd}$ from shoots to grains. In the five cultivars, compared with the high-Cd accumulator ZM18, the four low-Cd accumulators possessed at least two pathways to decrease the grains $\mathrm{Cd}$ concentration (Fig. 4A). The first way was to reduce the directly transport of $\mathrm{Cd}$ from roots to grains, and the redistribution of $\mathrm{Cd}$ from lower stems, older leaves, flag leaves and rachis to grains. The second way was to decrease the $C d$ redistribution from lower stems and older leaves to grains (Fig. 4A). Therefore, it seemed that the redistribution of $\mathrm{Cd}$ from lower stems and older leaves to grains had larger effect on varietal differences in grain $\mathrm{Cd}$ accumulation among these cultivars than the direct transport of $\mathrm{Cd}$ from roots to grains and the redistribution of $\mathrm{Cd}$ from flag leaves and rachis to grains.

(2) High-Cd stress changed the pathway of Cd accumulation in grains when compared with low Cd stress. Although the grain $\mathrm{Cd}$ accumulation in common wheat under high-Cd stress was affected by the $\mathrm{Cd}$ accumulation in each tissue and the $\mathrm{Cd}$ translocation from roots to new shoot tissues (including grains, rachis, internode 1 and flag leaves), it seemed that the different $\mathrm{Cd}$ accumulation in grains of these five cultivars practically came from the variant ability of Cd uptake. Thus, the higher Cd uptake by roots in YM53, SM969 and ZM18 led to the higher Cd accumulation in grains than YM51 and CM104 (Fig. 4B).

(3) For the five wheat cultivars, it is interesting that although the low/high Cd stress in soil changed the pathway of grains Cd accumulation, YM51 and CM104 showed the similar pathway in low-Cd stress, and the 
similar pathway in high-Cd stress, respectively. Likewise, similar results were obtained for YM53 and SM969.

For the high-Cd accumulator cultivar ZM18, no matter under low or high-Cd stress, it still accumulated high Cd concentration among these five cultivars.

\section{Abbreviations}

$\mathrm{Cd}$

Cadmium

YM51

Yunmai 51

YM53

Yunmai 53

SM969

Shumai 969

CM104

Chuanmai 104

ZM18

Zhoumai 18

TF

Translocation factor

RF

Redistribution factor

Declarations

\section{Ethics approval and consent to participate}

Not applicable

\section{Consent for publication}

Not applicable

\section{Availability of data and materials}

All data supporting the conclusions of this article are provided within the article.

\section{Competing interests}

The authors declare that they have no competing interests. 


\section{Funding}

This work was funded by the National Natural Science Foundation of China (No 31671688) for all financial support. The funder did not play any roles in the design of the study, collection, analysis and interpretation of the relevant data.

\section{Authors' contributions}

$Y W$ and $Y Z$ conceived and designed the experiments. $Y C$ and $Y W$ analyzed data and wrote the article. $Y C, X Z$, SW conducted experiments. XX, JZ, HK, XF, LS, HZ provided suggestions and comments to the manuscript. All authors reviewed and approved the manuscript.

\section{Acknowledgements}

We thank Prof. Jun Li, from Crop Research Institute, Sichuan Academy of Agricultural Sciences, for kindly supplying the seeds of wheat cultivars. We also thank Jennifer Smith, PhD, from Liwen Bianji, Edanz Group China (www.liwenbianji.cn/ac), for editing the English text of a draft of this manuscript.

Supplementary Table 1. Soil elements concentration at Wenjiang in the 2016-2017 wheat growing season.

Values were means \pm standard deviation (three biological repetitions). Different letters above the bars indicate significant level at $P \leq 0.05$ by the Duncan's test among the treatments.

Supplementary Table 2. Correlation analyses between grains $\mathrm{Cd}$ concentration with $\mathrm{Cd}$ concentration in roots, Cd concentration in shoots, and Cd translocation from roots to shoots at the seedling stage, respectively.

Pearson Correlation was used to analyze the correlations among different treatments.

Supplementary Table 3. Soil elements concentration at Wenjiang and Shifang experiment field in the 20152016 wheat growing season.

Values were means \pm standard deviation (three biological repetitions). Different letters above the bars indicate significant level at $P \leq 0.05$ by the Duncan's test among the treatments.

\section{References}

1. Arduini I, Masoni A, Mariotti M, Pampana S, Ercoli L. Cadmium uptake and translocation in durum wheat varieties differing in grain-Cd accumulation. Plant Soil Environment. 2014;60:43-9.

2. Chan DY, Hale BA. Differential accumulation of $\mathrm{Cd}$ in durum wheat cultivars: uptake and retranslocation as sources of variation. J Exp Bot. 2004;55:2571-9.

3. Chen F, Wu F, Dong J, Vincze E, Zhang G, Wang F, Huang Y, Wei K. Cadmium translocation and accumulation in developing barely grains. Planta. 2007;227:223-32. 
4. Cheng Y, Wang C, Chai S, Shuai W, Sha L, Zhang H, Kang H, Fan X, Zeng J, Zhou Y, Wang Y. Ammonium N influences the uptakes, translocations, subcellular distributions and chemical forms of $\mathrm{Cd}$ and $\mathrm{Zn}$ to mediate the $\mathrm{Cd} / \mathrm{Zn}$ interactions in dwarf polish wheat (Triticum polonicum L.) seedlings. Chemosphere. 2018;193:1164-71.

5. Clemens S, Palmgren MG, Krämer U. A long way ahead: understanding and engineering plant metal accumulation. Trend in Plant Science. 2002;7:309-15.

6. Grant C, Clarke J, Duguid S, Chaney R. Selection and breeding of plant cultivars to minimize cadmium accumulation. Sci Total Environ. 2008;390:301-10.

7. Greger M, Landberg T. Role of rhizosphere mechanisms in Cd uptake by various wheat cultivars. Plant Soil. 2008;312:195-205.

8. Greger M, Löfstedt M. Comparison of uptake and distribution of cadmium in different cultivars of bread and durum wheat. Crop Sci. 2004;44:501-7.

9. Guttieri MJ, Baenziger PS, Frels K, Carver B, Arnall B, Wang S, Akhunov E, Waters BM. Prospects for selecting wheat with increased zinc and decreased cadmium concentration in grain. Crop Sci. 2015;55:1712-28.

10. Harris NS, Taylor GJ. Remobilization of Cadmium in maturing shoots of near isogenic lines of durum wheat that differ in grain cadmium accumulation. J Exp Bot. 2001;52:1473-81.

11. Harris NS, Taylor GJ. Cadmium uptake and partitioning in durum wheat during grain filling. BMC Plant Biol. 2013;13:103.

12. Jafarnejadi AR, Homaee M, Sayyad G, Bybordi M. Large scale spatial variability of accumulated cadmium in the wheat farm grains. Soil Sediment Contamination. 2011;20:98-113.

13. Kobayashi NI, Tanoi K, Hirose A, Nakanishi TM. Characterization of rapid intervascular transport of cadmium in rice stem by radioisotope imaging. J Exp Bot. 2013;64:507-17.

14. Koike S, Inoue H, Mizuno D, Takahashi M, Nakanishi H, Mori S, Nishizawa NK. OsYSL2 is a rice metalnicotianamine transporter that is regulated by iron and expressed in the phloem. Plant J. 2004;39:415-24.

15. Kubo K, Kobayashi H, Fujita M, Ota T, Minamiyama Y, Watanabe Y, Nakajima T, Shinano T. Varietal differences in the absorption and partitioning of cadmium in common wheat (Triticum aestivum L.). Environ Exp Bot. 2016;124:79-88.

16. Kubo K, Watanabe Y, Matsunaka H, Seki M, Fujita M, Kawada N, Hatta K, Nakajima T. Differences in cadmium accumulation and root morphology in seedlings of Japanese wheat varieties with distinctive grain cadmium concentration. Plant Production Science. 2011;14:148-55.

17. Kubo K, Watanabe Y, Oyanagi A, Kaneko S, Chono M, Matsunaka H, Seki M, Fujita M. Cadmium concentration in grains of Japanese wheat cultivars: Genotypic difference and relationship with agronomic characteristics. Plant Production Science. 2008;11:243-9.

18. Li H, Luo N, Li YW, Cai QY, Li HY, Mo CH, Wong MH. Cadmium in rice: Transport mechanisms, influencing factors, and minimizing measures. Environ Pollut. 2017;224:622-30.

19. Liang X, Strawn DG, Chen J, Marshall J. Variation in cadmium accumulation in spring wheat cultivars: uptake and redistribution to grain. Plant Soil. 2017;421:219-31. 
20. Liao QL, Huang SS, Lin RZ, Fan DF, Jin Y, Zhu BW. Element distribution characteristics of Cd-rich soils and their pollution remediation test in the lower reaches of the Yangtze River. Geology in China. 2008;3:51423. (in Chinese).

21. Liu C, Guttieri MJ, Waters BM, Eskridge KM, Easterly A, Baenziger PS. Cadmium concentration in terminal tissues as tools to select low-cadmium wheat. Plant Soil. 2019;430:127-38.

22. Liu J, Qian M, Cai G, Yang J, Zhu Q. Uptake and translocation of Cd in different rice cultivars and the relation with Cd accumulation in rice grain. J Hazard Mater. 2007;143:443-7.

23. Liu F, Liu XN, Ding C, Wu L. The dynamic simulation of rice growth parameters under cadmium stress with the assimilation of multi-period spectral indices and crop model. Field Crops Research. 2015;183:225-34.

24. Liu X, Tian G, Jiang D, Zhang C, Kong L. Cadmium (Cd) distribution and contamination in Chinese paddy soils on national scale. Environ Sci Pollut Res. 2016;23:17941-52.

25. Liu YP, He ZW, Kan ZZ. Distribution of Cadmium in Chengdu Plain and controlling factors. Environmental Science Information Application Technology. 2010;10:660-3.

26. Perrier F, Yan B, Candaudap F, Pokrovsky OS, Gourdain E, Meleard B, Bussière S, Coriou C, Robert T, Nguyen C, Corny JY. Variability in grain cadmium concentration among durum wheat cultivars: impact of aboveground biomass partitioning. Plant Soil. 2016;404:307-20.

27. Pozniak CJ, Clarke JM, Clarke FR. Potential for detection of marker-trait associations in durum wheat using unbalanced, historical phenotypic datasets. Mol Breeding. 2012;30:1537-50.

28. Qian S, Wang YY, Xiang QS. The distribution character and analysis of anomaly sources of Cd in the agricultural soil in Deyang city. Environmental Monitoring in China. 2014;2:80-4.

29. Rodda MS, Li G, Reid RJ. The timing of grain Cd accumulation in rice plant: the relative important of remobilization within the plant and root Cd uptake post-flowering. Plant Soil. 2011;347:105-14.

30. Shi G, Zhu S, Bai SM, Xia Y, Lou L, Cai Q. 2015. The transportation and accumulation of arsenic, cadmium, and phosphorus in 12 wheat cultivars and their relationships with each other. Journal of Hazardous Materials, 2015, 299: 91-102.

31. Shi G, Li J, Wang Y, Liu C, Hu Z, Lou L, Rengel Z, Cai Q. Accumulation and distribution of arsenic and cadmium in winter wheat (Triticum aestivum L.) at different developmental stages. Sci Total Environ. 2019;667:532-9.

32. Stolt $\mathrm{P}, \mathrm{Asp} \mathrm{H}$, Hultin S. Genetic variation in wheat cadmium accumulation on soils with different cadmium concentration. J Agron Crop Sci. 2006;192:201-8.

33. The Codes Alimentarius Commission. 2005. Reports of the 37th session of the Codex committee on food additives and contaminants. The Hugue, the Netherlands, 25-29 April, 2005. WHO/FAO. Rome. 184.

34. The Ministry of Environmental Protection. 2014. The ministry of land and resources report on the national soil contamination survey.

35. Ueno D, Yamaji N, Kono I, Huang CF, Ando T, Yano M, Ma JF. Gene limiting cadmium accumulation in rice. Proc Natl Acad Sci USA. 2010;107:16500-5.

36. Uraguchi S, Fujiwara T. Cadmium transport and tolerance in rice: perspectives for reducing grain cadmium accumulation. Rice. 2012;5:5. 
37. Wang Y, Wang C, Liu Y, Yu K, Zhou Y. GmHMA3 sequesters $\mathrm{Cd}$ to the root endoplasmic reticulum to limit translocation to the stems in soybean. Plant Sci. 2018;270:23-9.

38. Wang Y, Xiao X, Zhang TQ, Kang HY, Zeng J, Fan X, Sha LN, Zhang HQ, Yu KF, Zhou YH. 2014. Cadmium treatment alters the expression of five genes at the Cda1 loucs in two soybean cultivars [Glycine Max (L.) Merr]. The Scientific World Journal, 2014, 979750.

39. Wiebe K, Harris NS, Faris JD, Clarke JM, Knox RE, Taylor GJ, Pozniak CJ. Targeted mapping of Cdu1, a major locus regulating grain cadmium concentration in durum wheat (Triticum turgidum $\mathrm{L}$. var durum). Theor Appl Genet. 2010;121:1047-58.

40. Yamaji N, Sasaki A, Xia JX, Yokosho K, Ma JF. A node-based switch for preferential distribution of manganese in rice. Nat Commun. 2013;4:2442.

41. Yan YF, Choi DH, Kim DS, Lee BW. Absorption, translocation, and remobilization of cadmium supplied at different growth stages of rice. Journal of Crop Science Biotechnology. 2010;13:113-9.

42. Yoneyama T, Gosho T, Kato M, Goto S, Hayashi H. Xylem and phloem transport of $\mathrm{Cd}$, Zn and Fe into the grains of rice plants (Oryza sativa L.) grown in continuously flooded Cd-contaminated soil. Soil Science Plant Nutrition. 2010;56:445-53.

43. Zhang G, Fukami M, Sekimoto H. Influence of cadmium on mineral concentrations and yield components in wheat genotypes differing in Cd tolerance at seedling stage. Field Crop Research. 2002;77:93-8.

44. Zhou N, Wang R. Phytoremediation-new approach of heavy metal clean up from heavy metal-polluted soils. Chin J Biotechnol. 2002;22:53-7. (in Chinese).

\section{Figures}




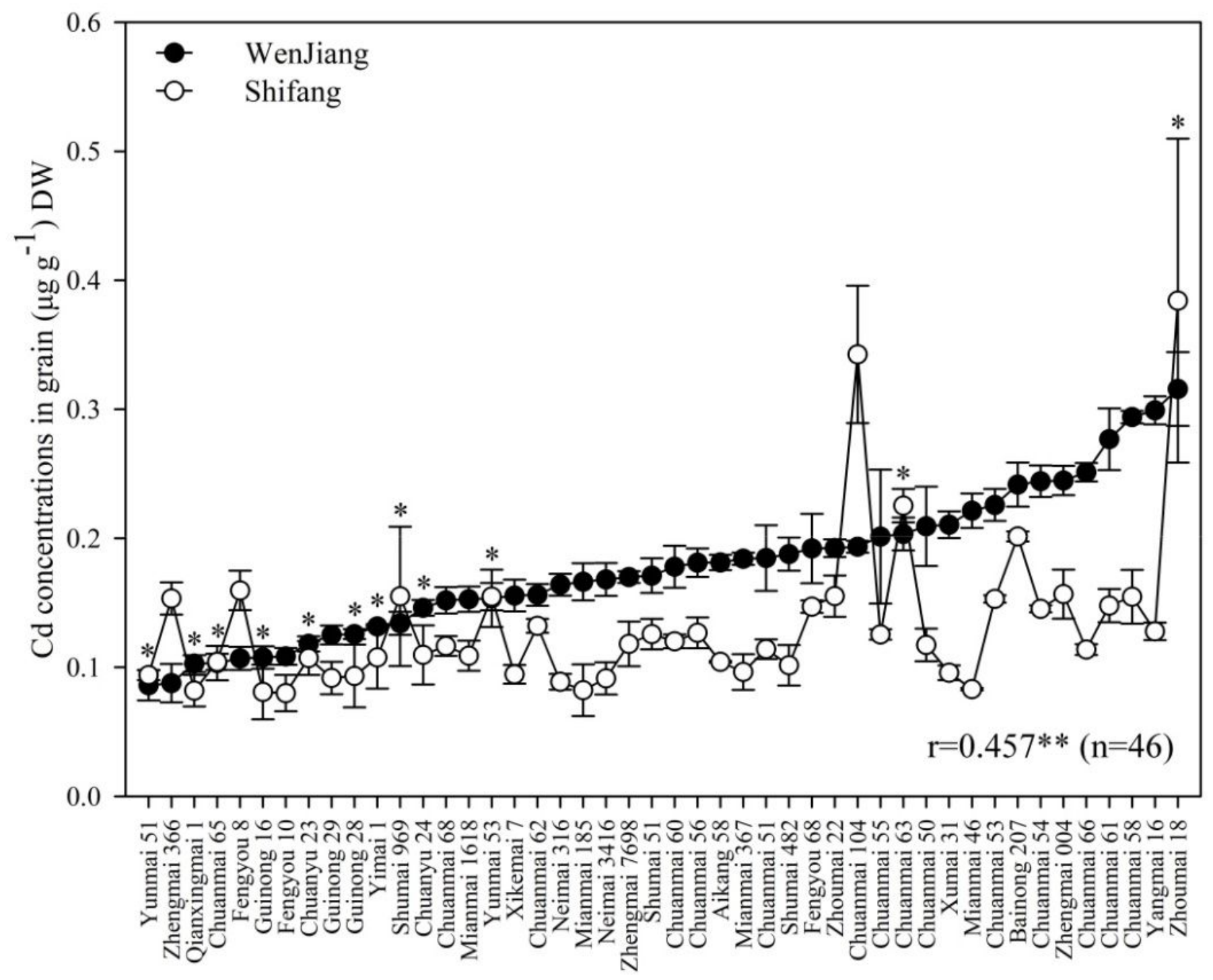

Figure 1

Grain Cd concentrations of different wheat cultivars at Wenjiang and Shifang, Sichuan, China. Values were means \pm standard deviation (three biological repetitions); * represented no different among grain $\mathrm{Cd}$ concentration of each cultivar between Shifang and Wenjiang sites at a level of significance $P \leq 0.05$. ** represented a significant correlation of grain Cd concentration in each cultivar between Wenjiang and Shifang at a level of significance $P \leq 0.01$. 

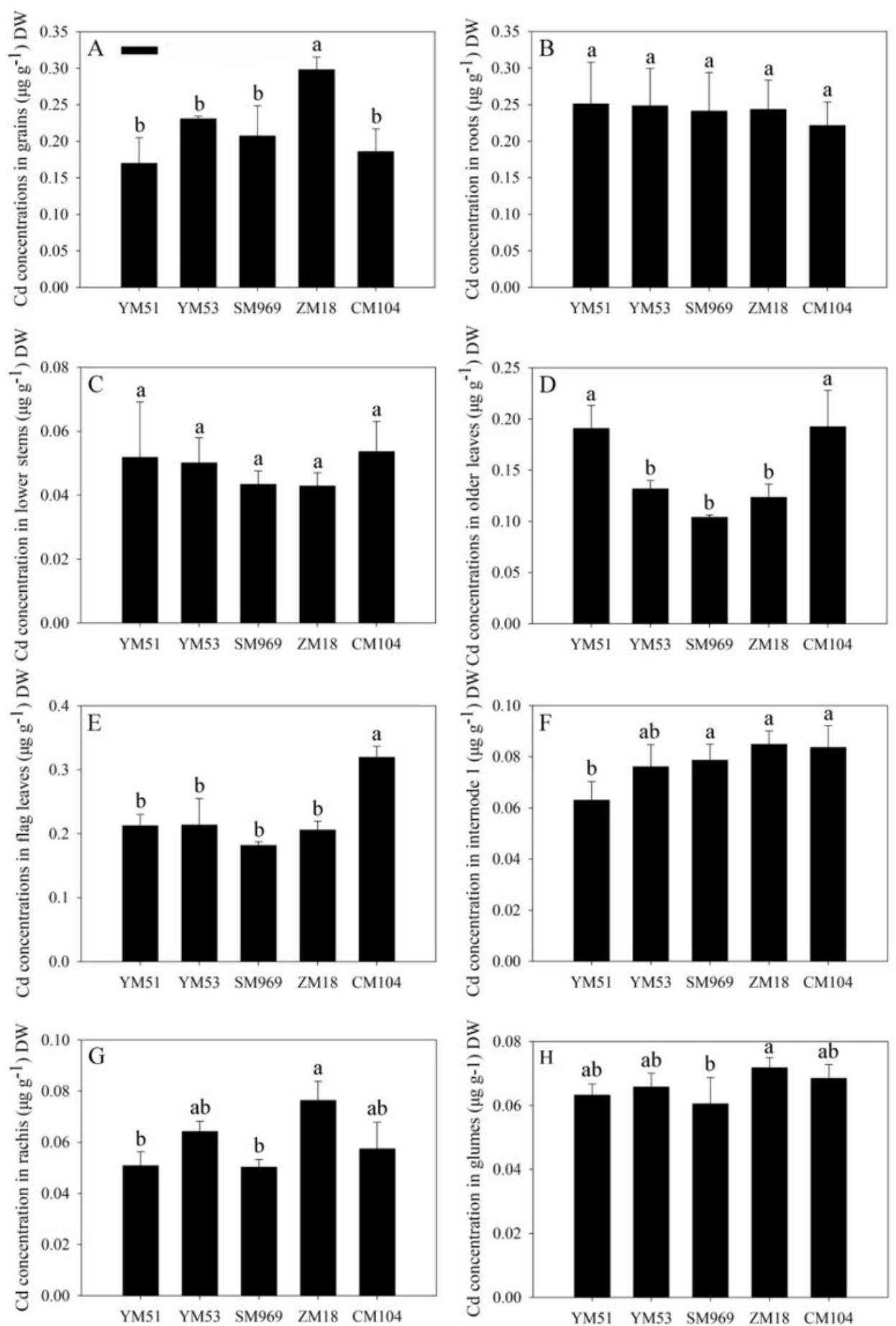

Figure 2

Cd concentrations in tissues of each cultivar under low-Cd stress. A-H represented the Cd concentrations in grains $(A)$, roots $(B)$, lower stems $(C)$, older leaves $(D)$, flag leaves $(E)$, internode $1(F)$, rachis $(G)$ and glumes $(H)$. Values were means \pm standard deviation (three biological repetitions). Different letters above the bars indicate significant level at $P \leq 0.05$ by the Duncan's test among the treatments. 

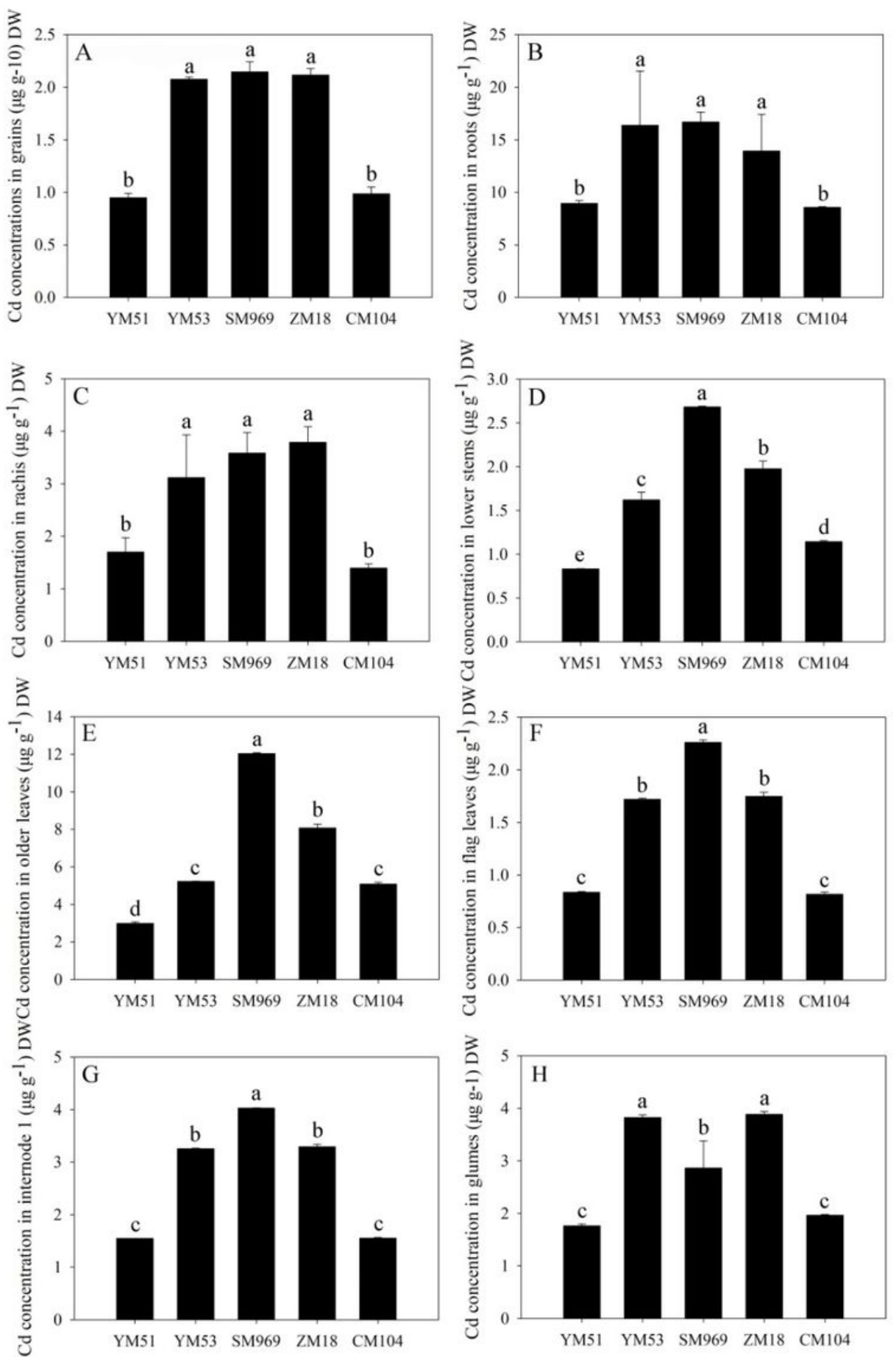

Figure 3

$\mathrm{Cd}$ concentrations in tissues of each cultivar under high-Cd stress. A-H represented the Cd concentrations in grains $(A)$, roots $(B)$, rachis $(C)$, lower stems $(D)$, older leaves $(E)$, flag leaves $(F)$, internode $1(G)$ and glumes $(H)$. Values were means \pm standard deviation (three biological repetitions). Different letters above the bars indicate significant level at $P \leq 0.05$ by the Duncan's test among the treatments. 
A
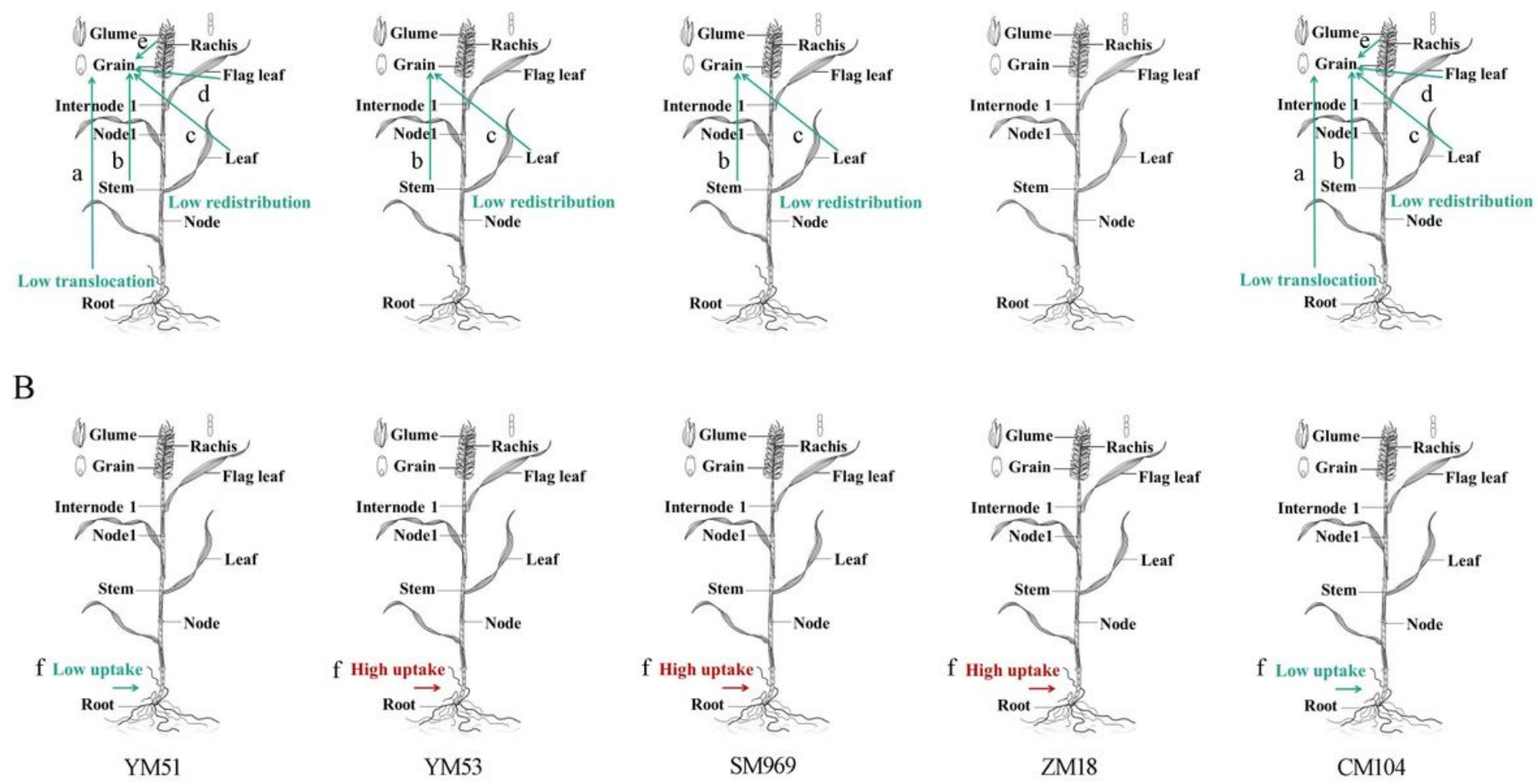

Figure 4

The mode of $\mathrm{Cd}$ transport pathway under low and high $\mathrm{Cd}$ stresses at the maturity stage. A: the mode of Cd transport pathway under low Cd stress; B: the mode of Cd transport pathway under high Cd stress. Route a: Cd translocation from roots to grains; route b/c/d/e: Cd redistribution from lower stems, older leaves, flag leaves and rachis to grains, respectively; route $\mathrm{f}$ : $\mathrm{Cd}$ uptake in roots.

\section{Supplementary Files}

This is a list of supplementary files associated with this preprint. Click to download.

- Supplementarytables20200415.docx 